\title{
BIOPESTICIDE USE AND RESEARCH IN BRAZIL
}

\begin{abstract}
Wagner Bettiol, Embrapa Environment, CP 69, $13820-000$ Jaguariúna, SP Brazil (bettiol@cnpma.embrapa.br), describes ongoing research and outlines the surge in interest for the use of biorational products in Brazil
\end{abstract}

Keywords: biocontrol, Brazilian market, plant disease, pests, pesticides

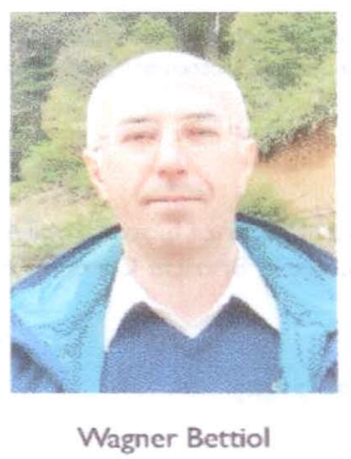

\section{Introduction}

Biopesticides are living microorganisms (fungi, bacteria, microsporidia and viruses), microscopic animals (nematodes) and macroorganisms (predators and parasitoids, insects and mites) or natural products derived from these organisms that are used as plant protection products.

The demand for biopesticides and biocompatible products to control pests, diseases and weeds has been increasing in Brazil in recent years, with increases in concern about the environment and contamination of food with synthetic chemical pesticides. It is also important to consider the expansion of the organic farming area and the move towards integrated pest management (IPM) in Brazil. This article provides an analysis and summary of the use of biopesticides in Brazil, including historic information, current use, research and technology development, marketing status and size, registration process, and opportunities for biocontrol agents.

\section{Pesticide market in Brazil}

Brazil is one of the world's largest consumer of chemical pesticides for agriculture with sales of almost US\$ 7.304 billion in 2010 (Figure 1) and estimated US $\$ 8.3$ billion for 2011. Herbicides are the most important with sales of US $\$ 2.428$ billion, followed by insecticides (US\$2.365 billion) and fungicides (US\$ 2.128 billion) (Figure 2). In general, biocontrol products represent around $1 \%$ of chemical pesticides sales (US\$ 65 to US\$ 75 million). Biocontrol agents for weeds are not marketed. Thus, considering that in the market there are only biocontrol agents for insects and plant diseases, the percentage of that market share rises to $2 \%$. Optimistic estimates project that sales of biopesticides could reach $10 \%$ in 2020 ,

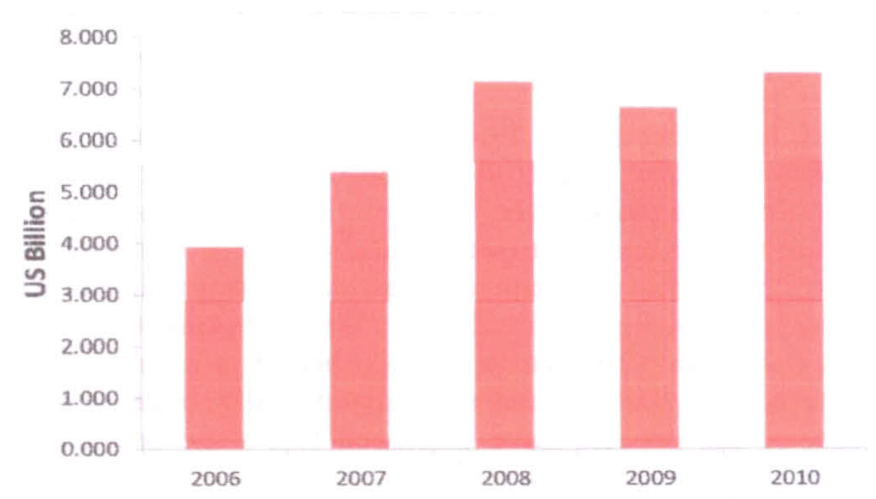

Figure 1. Brazil agrochemical sales, 2006 to 2010 (US billion of dollars). Source: Sindag (2011).

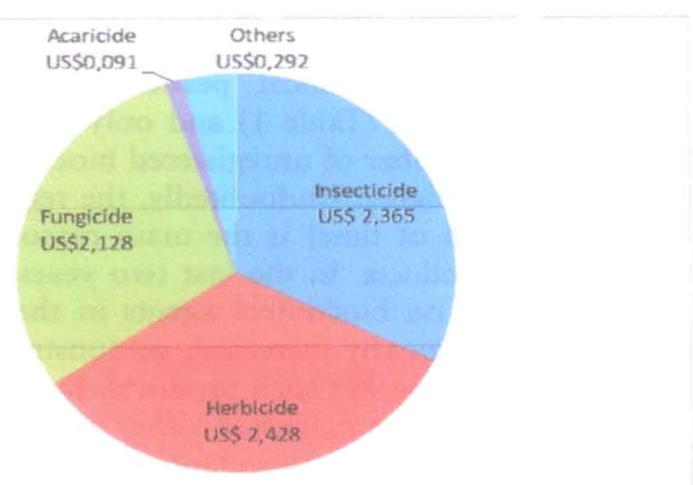

Figure 2. Brazil's agrochemical sales by product category, 2010 in millions of dollars. Source: Sindag (20!1).

but research and development and regulation are critical if this is to be achieved.

In Brazil, biocontrol products based on macro- and microorganisms are considered to be plant protection products with the same regulations for registration and use as for chemical pesticides. Undoubtedly, the registration process is one of the main reasons for the low market share of biopesticides in Brazil. Concerns by authorities regarding environmental health and safety have led to regulatory changes in the last few years to facilitate/stimulate the registration of biopesticides. In Brazil, these authorities are working to establish specific legislation for the registration of biopesticides, and a decree establishing the criteria for registration of biopesticides for organic agriculture was approved in July 2009 which has simplified the registration process. The greatest remaining challenges are: to approve a specific regulation for registration 
of biopesticides; to reduce the period (now 4-5 years) and expense for registering biopesticides; to exempt registration for macro-organisms used as biopesticides; and to establish the registration of biopesticides considering the target pest and not the crops.

In October 2007, the Brazilian Biocontrol Manufacturers' Association (ABCBIO) was created to organize this sector. Currently, ABCBIO has 23 Brazilian companies associated with it. In July 2009, concurrently with the work of ABCBIO, a workshop was organized by Embrapa Environment and Agricultural Ministry to discuss "Advantages of registration of biological products for pest and disease control". These actions have resulted in more than 80 submissions to obtain temporary special registration, the first step to registration of biocontrol agents, after July 2009. Possibly, these actions coupled with the market interest and demands of society will lead to the number of registered products containing biocontrol agents growing in Brazil soon. We are optimistic, and we think that within two years the number of biocontrol agents registered in Brazil will increase substantially, because all the actors of the process have discussed this issue and tried to make consistent changes.

\section{Biopesticides market in Brazil}

Biological Control Agents (BCAs) represent only a small percentage of registered pesticides in Brazil. In August 2011, there were 1352 chemical pesticides (formulations and mixtures) registered (Table 1) and only 26 BCAs (Table 2). However, the number of unregistered biocontrol agent products sold is far higher. Undoubtedly, the registration process (cost and length of time) is the main reason for the use of unregistered products. In the last two years, the number of products based on biocontrol agents in the initial stage of registration has greatly increased, demonstrating the interest of companies to market such products. Furthermore, several biocontrol agents are marketed either as growth promoters, compost, biofertilizers or inoculants when they do not need to undergo the registration process as pesticides, with the regis tration process simpler and faster.

Baculovirus anticarsia (virus), Bacillus thuringiensis, Bacillus subtilis, and Bacillus pumilus (bacteria), Aspergillus flavus NRRL 21882, Beauveria bassiana, Metarbizium anisopliae, Trichoderma asperellum, and Trichoderma harzianum (fungi), Steinernema puertoricense (nematode), Ceratitis capitata (sterile male), Cotesia flavipes, and Trichogramma galloi (parasitoid wasps) are the registered biocontrol species. The most important species traded are Cotesia and Trichogramma to control Diatraea saccharalis (sugarcane borer) on sugarcane on about 3 and 0.5 million ha, respectively; Metarhizium anisopliae to control Mahanarva (spittlebug) on sugarcane on about 2 million ha; Trichoderma spp. to control several soil borne plant pathogen on almost 1.5 million ha; Bacillus thuringiensis on almost 0.3 million ha to control caterpillars; Baculovirus anticarsia to control Anticarsia gemmatalis (velvetbean caterpillar) on soybean on 0.3 million ha; and Metarbizium anisopliae in pasture for the control of Mahanarva posticata (little cicada of sugarcane) on about 60,000 ha. Besides these species, others are sold with-
Table 1. Number of commercial products by category registered as agricultural pesticides in Brazil in August 2011.

\begin{tabular}{lc} 
Pesticide & Number \\
\hline Herbicide & 485 \\
Insecticide & 406 \\
Fungicide & 377 \\
Acaricide & 143 \\
Pheromone & 43 \\
Nematicide & 25 \\
Bactericide & 14 \\
Others & 56 \\
Total & 1352
\end{tabular}

Source: http://www.agricultura.gov.br/portal/page/portal//nternet-MAFA/ pagina-inicial/servicos-e-sistemas/sistemas/agrofit (August 10,2011).

Table 2. Species and number of biocontrol agents registered as agricultural biopesticides in Brazil in October 2011.

\begin{tabular}{lc} 
Bioagent & Number \\
\hline Aspergillus flavus NRRL 21882 & 1 \\
Bacillus thuringiensis & 9 \\
Bacillus subtilis & 1 \\
Bacillus pumilus & 1 \\
Baculovirus anticarsia & 3 \\
Beauveria bassiana & 1 \\
Ceratitis capitato (esterile male) & 1 \\
Cotesia flavipes & 1 \\
Metarhizium anisopliae & 3 \\
Steinernema puertoricense & 1 \\
Trichogramma galloi & 1 \\
Trichoderma asperellum & 1 \\
Trichoderma harzianum & 1 \\
Other & 1
\end{tabular}

Source: hrtp://www.agricultura.gov.br/portal/page/portal/internet-MAPA/ pagina-inicial/servicos-e-sistemas/sistemas/agrofit (October, 2011).

out registration: Bacillus subtilis, Bacillus licheniformis, and Bacillus thuringiensis (bacteria); Beauveria bassiana, Clonostachys rosea, Isaria sp., Lecanicillium lecanii, Lecanicillium longisporum, Metarhizium anisopliae, Paecilomyces lilacinus, Pochonia chlamidosporia, Trichoderma asperellum, Trichoderma harzianum and other Trichoderma spp. (fungi); Orius insidiosus, Neoseulus californicus, Phytoseiulus macropilus and Podisus nigrispinus (mites) and others. Regulatory and bureaucratic problems seem to be responsible for the high number of such illegal biocontrol products in Brazil.

An indication of the increased demand for biocontrol agents can be seen with data from the use of Trichoderma. Trichoderma-treated area in 2008 was 600,000 ha and in 2010 this number grew to over $1,200,000$ ha, showing an increase of approximately $100 \%$ in three years. The demand for this BCA should increase in coming years because it is an alternative for the control of white mold, caused by Scierotinia sclerotiorum, on soybeans, currently the country's most important crop with a steadily increasing acreage. 


\section{BIOPESTICIDE USE AND RESEARCH IN BRAZIL}

\section{Examples of successes in biocontrol}

Tristeza virus practically wiped out the citrus industry in Brazil in the $1940 \mathrm{~s}$. The recovery was due to combination of tolerant rootstocks and premunization (cross protection) with the mild strains of tristeza virus. Since 1968 , citrus plants with the unregistered mild strains virus (66 and 141) have been commercialized in Brazil and over 200 million premunizated trees are currently being cultivated. Sugarcane is an important crop in Brazil with around 7 million ha. Biological control has been used on a large scale since the 1970 s. Cotesia flavipes and Trichogramma galloi have been used to control Diatraea saccharalis on sugarcane. These parasitoids have been released on around 3.5 million ha/year. Until 2010, these parasitoids had been released on around 3.5 million ha/year, without registration. These examples - the most important in Brazil illustrate the situation of regulations for BCAs. However, for over 50 years these agents and others have been used without registration, without any environmental problems, without any health problems, and with economical success.

These examples illustrate the status and challenges for biocontrol agents in Brazil. It is important to highlight that we need to continue using biocontrol because it is indispensable for agribusiness; to urgently regularize the situation of these and other biocontrol agents; to increase the use of biocontrol agents to reduce the environmental impacts of chemical pesticides; and to develop new products to meet the increasing market demands as soon as possible.

\section{Development of biological control}

The history of development of biocontrol in Brazil is different for each of the pest problems. We list below chronologies for the biocontrol of plant diseases and insects. Biological control of weeds is much more limited in our country, so the very limited history is not provided.

\section{Biological control of plant disease}

1950 - First paper on biocontrol published in Brazil (Forster, R. 1950. Inativação do vírus do mosaico comum do fumo pelo filtrado de cultura de Trichoderma sp. Bragantia 10: 139-148).

1986 - First Brazilian meeting on biological control of plant disease;

1987 - First commercial product based on Trichoderma viride to control Phytophthora cactorum in apple;

1991 - First book and first post-graduate discipline on biological control of plant disease;

1992 - First company specialized in the production and trade of Trichoderma;

2007 - IX Brazilian Meeting on biological control of plant diseases and establishment of Brazilian Biocontrol Manufactures' Association (ABCBIO);

2008 - First commercial product registered for the control of plant diseases, based on Trichoderma, and over 30 trademarks of biological products for disease control;

2010 - More than 1 million ha treated with Trichoderma to control soil borne disease;

2011 - Establishment of the first graduate discipline of biological control of plant disease.

\section{Biological control of insects}

1888 - Introduction of Rodolia cardinalis to control Icerya purchasi in citrus:

1950 - Control of the sugarcane borer with native taquinidies;

1962 - First Brazilian Symposium of Biological Control of Pests at the Institute of Ecology and Agricultural Experimentation, Rio de Janeiro;

1964 - First post-graduation entomology discipline in Brazil; 1968 - Book about insects living on plants in Brazil and its predators and parasites;

1971 - Introduction of Cotesia flavipes to control sugarcane borer;

1971 - Programs of biological control of forest pests with the importation of parasitoids from Trinidad;

1972 - Program of pest control with Metarbizium anisopliae; 1973 - First post-graduation discipline on Biological control of pests;

1974 - First course on Insect pathology;

1979 - Control program with Baculovirus anticarsia to control Anticarsia gemmatalis;

1986 - First book about microbial control of insects;

1987 - First Brazilian Biological Control Symposium;

2005 - Electronic Journal "Bioassay" was put out to broadcast research into biocontrol agents;

2008 - First commercial product registered for the control of insects, based on Metarbizium anisopliae, and over 25 trademarks of biological products for pest control;

2010 - Cotesia flavipes and Trichogramma galloi were registered to control Diatraea saccharalis on sugarcane;

2011 - 12th Brazilian Biological Control Symposium.

\section{Society's views on biopesticides}

In recent years the popularity of biopesticides has increased not only among farmers and different segments of society, but also among experts from the chemical pesticide companies. The development of biopesticides has become a priority with the funding agencies for research and development, as well as among various research institutions. An important aspect is that the farmers are looking for alternative techniques for the control of plant health problems, both seeking to reduce costs and to attend to society's demand for foods which are free from chemical pesticides.

\section{Organic agriculture}

Although it is considered that organic farming and biopesticides go together, in Brazil a major market for biopesticides is currently conventional agriculture. However, considering the growth of around $5 \%$ a year in cultivated area with organic farming, this agricultural system will soon represent an important potential market for biopesticides in Brazil.

\section{What is missing in Brazil for the development of biopesticides?}

1. Changing the approach/culture of farmers, agronomists and researchers and others to biological control; 
2. Basic research with bioagents, including environmental impact assessments;

3. Increased number of laboratories working with insect rearing techniques, screening of antagonists and technology for multiplication/production, to avoid promoting low quality companies;

4. Changes in the relationships between companies and research institutions to develop collaborative projects combining industrial expertise in research and development and fundamental and applied microbiology, entomology, and agronomy;

5. Analysis of market size and competing products;

6. Commercialization of products only after certainty of efficiency;

7. Quality control of the marketed products;

8. Adjustment in the scale of production and distribution logistics and transportation;

9. Training on the use and integration of biopesticides into cropping systems;

10. Appropriate public policy for biological control, through fiscal and credit incentives;

11. Regulations for research, development, and registration of biopesticides.

\section{Final considerations}

The early studies of applied entomology and phytopathology in Brazil were greatly influenced by agrochemicals. Therefore, there is a cultural problem of acceptance of biological control. Along with the cultural aspect, the agricultural model adopted in Brazil is also detrimental to the implementation of biological control because it is based on continuous cultivation of only a few crops over large areas. However, this system can be beneficial to biological control when there is no chemical pesticide to solve the problems of insects and diseases, e.g. the sugarcane borer and white mold of soybean. However, we need to readopt the practices of integrated pest management so that biological control can consistently grow. For example, in the 1980 s Baculovirus anticarsia was applied on more than two million ha to control Anticarsia gemmatalis in soybean. This number has been reduced to about 300,000 ha today due to the decrease in the use of IPM in soybean.

A problem of concern is the Convention on Biological Diversity (Rio de Janeiro, Bonn and Nagoya), with its concept of Access and Benefit Sharing (ABS), which impairs the access to natural enemies for biological control. For example, most research with biological control in Brazil is illegal, both because of the legal aspects of access to genetic resources and to the regulations for registration of biopesticides. However, we are optimistic about the growing market for biopesticides in Brazil and we estimate that sales of these products may reach $10 \%$ of the pest management product market in 2020 .

\section{Acknowledgments}

I would like to thank Dr. Steve Duke for the contribution in suggesting and reviewing this manuscript; and Dr. Parra for the useful information on biological control of insects in Brazil.

\section{Reference}

Sindag 2011. Dado oficial revela movimentação de US7,3 bi em 2010. Ano $05, \mathrm{n}^{\circ} 29, \mathrm{p} .4$

Wagner Bettiol is a plant pathology scientist at Brazilian Agricultural Research Corporation's. Embrapa Environment, whose research interest includes biological and biorational control of plant disease. He is currently associate editor of Tropical Plant Pathology and head of the Environmental Microbiology Laboratory. He has a Ph.D. from University of São Paulo, Brazil and a post-doc from Turin University, Italy.

\section{SUBSCRIBERS - REGISTER FOR FREE ONLINE ACCESS VIA INGENTA}

Registering your institution is quick and easy; the whole process involves 4 simple steps and should take you no more than 5 minutes. Please have ready the following information:

\section{Contact details}

- As administrator, your basic contact details

- Your library/institution's name and address

\section{Authentication}

Access to IngentaConnect can be set up in two ways. You may choose one or both methods of authentication.

- IP address/range (users accessing from computers within an IP range defined by the site administrator) -

You may need to consult your network administrator for this information.

- User name and password.

https:/www.ingentaconnect.com/register/institutional 